\title{
Distribution and Transition of Heavy Metals in Mine Tailing Dumps
}

\author{
Keiko Sasaki ${ }^{1, *}$, Takanori Haga ${ }^{2}$, Tsuyoshi Hirajima ${ }^{2}$, Kunihiko Kurosawa ${ }^{3}$ \\ and Masami Tsunekawa ${ }^{2}$ \\ ${ }^{1}$ Laboratory of Environmental Science, Otaru University of Commerce, Otaru 047-8501, Japan \\ ${ }^{2}$ Graduate School of Engineering, Hokkaido University, Sapporo 060-8628, Japan \\ ${ }^{3}$ Geological Survey of Hokkaido, Sapporo 060-0819, Japan
}

The vertical distributions of heavy metals and other elements in sediment core samples in a landfill of abandoned mine tailings were examined. Core samples were analyzed by XRF and XRD, and further examined by ICP-AES measurements after acid-sequential extraction with $\mathrm{HCl}, \mathrm{HF}$, and $\mathrm{HNO}_{3}$. According to XRD, the sediments contained $\alpha$-quartz as the main component, and sericite, chlorite, rhodochrosite, pyrite, jarosite, sphalerite, and galena as minor components. A complete decomposition method using sequential extraction for the mine tailings sediments was established at ambient temperatures. Acid sequential extraction was useful for the analysis of minerals in mine tailings which are difficult to detect by XRD. Rhodochrosite and chlorite were dissolved by HCl-extraction, quartz and sericite by HF-extraction, and sulfides by $\mathrm{HNO}_{3}$-extraction. Rhodochrosite was the main source of high concentrations of $\mathrm{Mn}$ in mine drainage, highly distributed below the $-100 \mathrm{~cm}$ zone in the mine tailings, combined with pyrite but not with sericite and quartz. The distributions of most heavy metals were related to those of pyrite.

(Received April 1, 2002; Accepted August 2, 2002)

Keywords: acid-sequential extraction, mine tailings, heavy metals, rhodochrosite, pyrite, quartz

\section{Introduction}

Acid mine drainage is an environmental problem around the world arising from the mining of sulfide ores. Mining produces waste rock and mill tailings, which contain quartz, sulfides, clay minerals, and so on in various amounts. The exposure of sulfides to weathering oxidants leads to acidification in mines and the release of toxic elements, such as $\mathrm{Pb}$, $\mathrm{Cd}$, and As which are mainly involved in sulfide minerals. ${ }^{1)}$ There have been many investigations of anthropogenic pollution in mine tailings and its rehabilitation. ${ }^{2,3)}$ The possibility of bioremediation using sulfate-reducing bacteria in mine tailings has also been examined. ${ }^{4,5)}$

There are a number of abandoned sulfide mines in Hokkaido, Japan. Some suffer from the common environmental problem that their mine drainage contains high concentrations of manganese. This may be closely related with the geology of Hokkaido: manganese carbonates (rhodochrosite, $\mathrm{MnCO}_{3}$ ) are common in manganese mines in west Hokkaido, Japan. Manganese carbonates are not very common worldwide and are known as vein type (so called Inakuraishi-type), while most manganese generally occurs in oxide forms (e.g. pyrolusite, $\mathrm{MnO}_{2}$ ) in deposits. Rhodochrosite is more easily dissolved than pyrolusite, and spillage of Mn-rich mine drainage is a serious and characteristic problem at abandoned mines in Hokkaido, Japan. ${ }^{6}$ However, the association of rhodochrosite with other minerals and the distributions of rhodochrosite in mine tailings are not well known. Manganese also affects to health of people, such as the diseases in the central nerves system, so that the concentration is limited to less than $10 \mathrm{ppm}$ for discharged waters and to less than $0.1 \mathrm{ppm}$ for the drinking water by WHO.

In mine tailings, the main primary minerals are quartz, and pyrite with secondary minerals such as goethite. ${ }^{7)}$ Re-

*Corresponding author: E-mail: keikos@res.otaru-uc.ac.jp leased heavy metals are incorporated in silicate minerals such as feldspar to form various types of clay minerals as secondary minerals. It is well known that clay minerals have ion-exchangeable, buffering, and moisture-preserving abilities. To understand the transportation of heavy metals and the rehabilitation of mine tailings, it is important to examine the distribution and chemical forms of heavy metals, and to clarify the relation of the distributions of heavy metal minerals to those of clay minerals. Generally, XRD is used for identification of minerals. However, trace or poorly crystalline minerals cannot be detected by only XRD.

In the present work, the vertical distribution of heavy metal ions in abandoned mine tailings in Hokkaido, Japan, was examined by sequential extraction, and the main source minerals of mine drainage is discussed based on the results of this sequential extraction.

\section{Material and Methods}

\subsection{Description of sampling sites}

The sampling site is a tailing dump of an anonymous mine in Japan. The ore minerals are mainly pyrite, sphalerite, chalcopyrite and galena, accessory Mn-minerals, the gangue minerals quartz and kaolin. The mine drainage, influenced by these mine tailings, is weakly acidic ( $\mathrm{pH} \mathrm{4.82)}$ and its composition is shown as follows $\left(\mathrm{mmol} \mathrm{L}^{-1}\right)$ : $\mathrm{K}, 0.316 ; \mathrm{Si}, 0.833$; S, 20.359; Fe, 0.118; Mn, 7.749; Pb, $8 \times 10^{-4}$; Zn, 1.017; $\mathrm{Ca}, 8.597 ; \mathrm{Mg}$, 2.653; Al, 0.196; Cu, not detected; As, not detected. The dissolved oxygen was $11.7 \mathrm{mg} \mathrm{L}^{-1}$ at $6^{\circ} \mathrm{C}$, and ORP was $444 \mathrm{mV}$. High concentrations of $\mathrm{Mn}$ are one problem with this water, and mine drainage has been discharged after neutralization.

Core samples were taken at two points in this landfill using a $7 \mathrm{~cm}$ diameter handauger in $20 \mathrm{~cm}$ sections from the surface down to $400 \mathrm{~cm}$. The distance between the two points was about $50 \mathrm{~m}$. The sediments were pictured. A part of them was 
packed in bags purged with $\mathrm{N}_{2}$ gas, and transported to the laboratory within two hours for tests of the activity of sulfatereducing bacteria (SRB) in the sediments. The others were carried out in open-air to examine the iron-oxidizing activity.

For sulfate-reducing bacteria, one gram of anaerobic sediment was diluted into $9 \mathrm{~mL}$ of the medium prepared as follows: $7.5 \mathrm{~mL}$ of $0.6 \%(\mathrm{w} / \mathrm{v}) \mathrm{KH}_{2} \mathrm{PO}_{4}, 7.5 \mathrm{~mL}$ of salt solution, $0.1 \mathrm{~mL}$ of $0.1 \%$ resazurin-Na, $50 \mathrm{mg}$ of cysteine$\mathrm{HCl} \cdot \mathrm{H}_{2} \mathrm{O}$, distilled water $85 \mathrm{~mL}, \mathrm{pH} 7.2-7.4, \mathrm{~N}_{2}$-atmosphere; the composition of salt solution is as follows: $0.6 \%(\mathrm{w} / \mathrm{v})$ $\mathrm{KH}_{2} \mathrm{PO}_{4}, 1.2 \%$ (w/v) $\mathrm{NH}_{4} \mathrm{Cl}, 1.2 \%$ (w/v) $\mathrm{NaCl}, 0.12 \%(\mathrm{w} / \mathrm{v})$ $\mathrm{MgCl}_{2} \cdot 6 \mathrm{H}_{2} \mathrm{O}, 0.12 \%$ (w/v) $\mathrm{CaCl}_{2} \cdot 2 \mathrm{H}_{2} \mathrm{O}$. Each sample suspension was taken with a capillaly tube to culture anaerobically at $30^{\circ} \mathrm{C}$ for three days using a kit for Bio-checker of SRB (Sanai Sekiyu Co. Ltd., Japan).

\subsection{Chemical analysis of core sediments}

Sediments were dried at $50^{\circ} \mathrm{C}$ overnight to supply to $\mathrm{X}$ ray fluorescence analysis (XRF), X-ray diffraction analysis (XRD), and sequential extraction. Major elements of the sediments were analyzed using an energy dispersive type Horiba MESA-500 X-ray fluorescence spectrometer. The powder Xray diffraction patterns of samples were collected by a JEOL JDX-3500 X-ray diffractometer with a monochromator under the following conditions: radiation, $\mathrm{Cu} \mathrm{K} \alpha, 30 \mathrm{kV}, 200 \mathrm{~mA}$; step scanning method; time constant, 0.5 second; angle range, $2.5-65 \mathrm{deg} / 2 \theta$. Minerals were identified based on the Joint Committee on Powder Diffraction Standards Data (JCPDS).

To elucidate the chemical forms of the main elements in each vertical fraction of the core samples, sequential extraction was carried out in a teflon vessel with the mixture of $1 \mathrm{~mol} \mathrm{~L}-1 \mathrm{HCl}, 46 \% \mathrm{HF}$, and conc. $\mathrm{HNO}_{3}$, according to the modified previous method, ${ }^{8)}$ as shown in Fig. 1. Generally, $\mathrm{HCl}$-soluble components are from salt type minerals, HFsoluble components from silicate group minerals, and $\mathrm{HNO}_{3}$ soluble components from sulfides and related minerals. Considering that quartz is the main component in mine tailings, $46 \% \mathrm{HF}$ was used in the present work. The present samples were completely dissolved in the final step with this method.

Each $2.5 \mathrm{~g}$ of dried sediment was added to a teflon vessel containing $20 \mathrm{~mL}$ of one $\mathrm{mol} \mathrm{L}^{-1} \mathrm{HCl}$, and the mixture was shaken for 16 hours at $30^{\circ} \mathrm{C}$, then centrifuged at $3000 \mathrm{rpm}$ for $20 \mathrm{~min}$ and decanted. The residue was washed with $10 \mathrm{~mL}$ deionized water at three times and all supernates were mixed. The $\mathrm{S}, \mathrm{Fe}, \mathrm{As}, \mathrm{Pb}, \mathrm{Cu}, \mathrm{Zn}, \mathrm{Si}, \mathrm{Al}, \mathrm{K}, \mathrm{Mg}, \mathrm{Mn}$ and $\mathrm{K}$ concentrations were determined by a SEIKO SPS 7800 inductively coupled plasma atomic emission spectroscopy (ICP-AES). After drying the residue (residue 1), XRD patterns were collected.

Residue 1 was added to a teflon vessel containing $30 \mathrm{~mL}$ of $46 \% \mathrm{HF}$, and the mixture was shaken for one hour at $30^{\circ} \mathrm{C}$, centrifuged at $3000 \mathrm{rpm}$ for $20 \mathrm{~min}$, and decanted. The supernatant was mixed to the following supernatants. The remaining residue was further added to $30 \mathrm{~mL}$ of $46 \% \mathrm{HF}$, and the mixture was shaken for 16 hours at $30^{\circ} \mathrm{C}$. Further, $5 \mathrm{~g}$ of boric acid was added to the mixture shaken for $8 \mathrm{~h}$ at $30^{\circ} \mathrm{C}$, centrifuged, and decanted. The residue was washed at three times with $10 \mathrm{~mL}$ boiling deionized water. All supernatants were mixed for the ICP-AES analysis. After drying, the residue (residue 2) was subjected to XRD measurements.

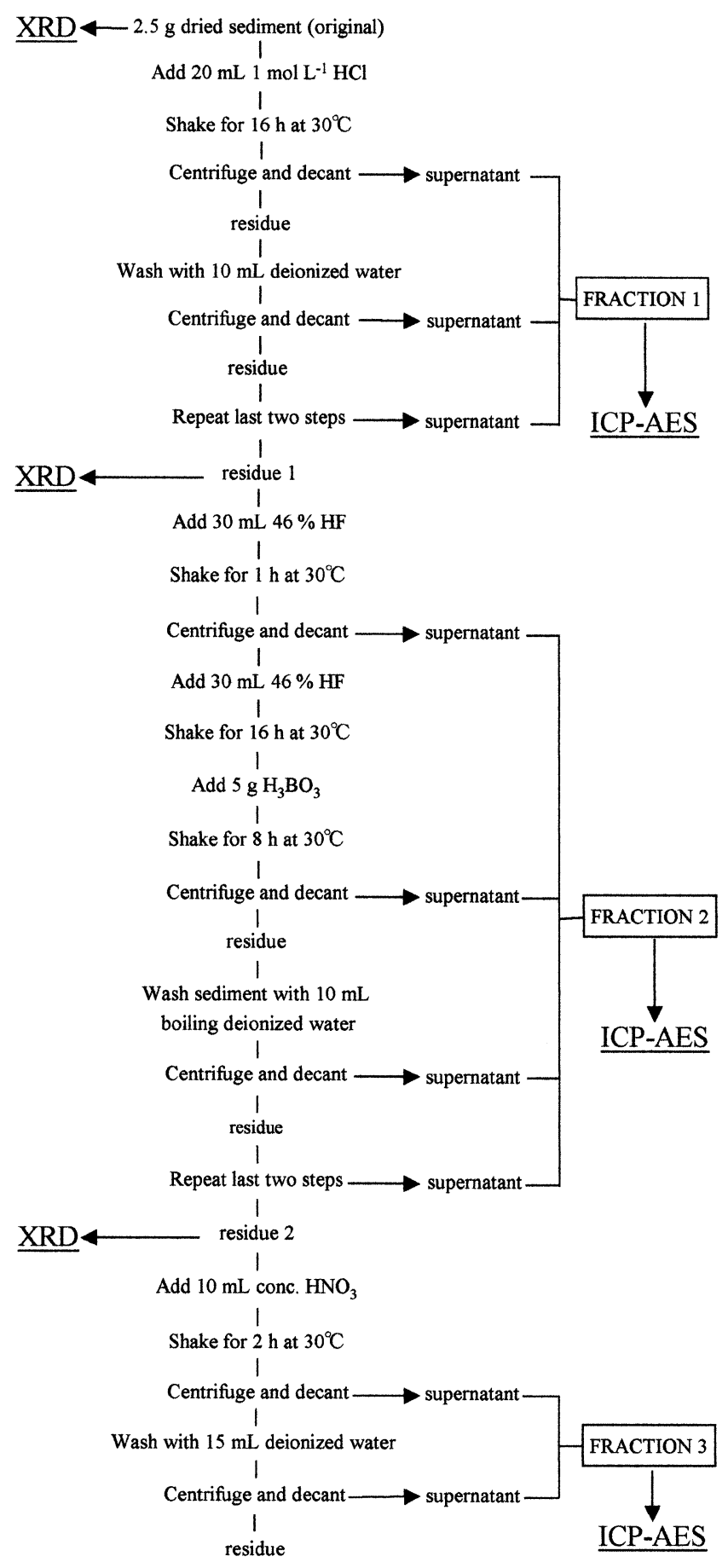

Fig. 1 Procedures of the acid sequential extraction.

Residue 2 was added to $10 \mathrm{~mL}$ of concentrated $\mathrm{HNO}_{3}$, shaken for $2 \mathrm{~h}$ at $30^{\circ} \mathrm{C}$, centrifuged, and decanted. The remaining residue was suspended in $15 \mathrm{~mL}$ of deionized water. After the mixture was centrifuged and decanted, the supernatant from both decantations were mixed for the ICP-AES measurements. In this method, the sediment samples were completely dissolved and no final residues were left for XRD measurements.

\section{Results and Discussion}

The XRF and XRD data of the core samples from the two different points were very similar, indicating that the vertical 
mineralogies of the two points in the mine tailing landfill are roughly unchanged. Therefore, the results from only one of the core-sample are shown as below.

According to the XRF results, $\mathrm{Si}$ is uniformly distributed independent of depth, at concentrations around 65-70\%. The $\mathrm{Al}$ content is $10-15 \%$ with higher concentrations in the upper zone. The Fe content is $12-22 \%$ also in the moderate range and maximum in the $-100 \sim-120 \mathrm{~cm}$ zone. The $\mathrm{Mn}$ and $\mathrm{S}$ contents were below $10 \%$, their distributions were extremely concentrated in the zone lower than $-100 \mathrm{~cm}$ depth. The contents of the other elements were below $5 \%$ in the sediment. It is considered that most of the $\mathrm{Si}$ is derived from the quartz in the mine tailings, and $\mathrm{Al}$ and $\mathrm{Fe}$ may be involved in clay minerals, sulfides and other soil substances.

The XRD patterns of the original core samples at all depths indicated that a major crystalline component is $\alpha$-quartz $\left(\mathrm{SiO}_{2}\right)$, and that sericite $\left(\mathrm{KAl}_{2} \mathrm{Si}_{3} \mathrm{AlO}_{10}(\mathrm{OH})_{2}\right)$, chlorite $\left(\left(\mathrm{R}_{6-x-3 y}^{2+} \mathrm{R}_{x+2 y}^{3+}\right)\left(\mathrm{Al}_{x} \mathrm{Si}_{4-x}\right) \mathrm{O}_{10}(\mathrm{OH})_{8}, \mathrm{R}^{2+}: \mathrm{Mg}^{2+}\right.$, $\left.\mathrm{Fe}^{2+}, \mathrm{Mn}^{2+}, \mathrm{Ni}^{2+}, \mathrm{R}^{3+}: \mathrm{Al}^{3+}, \mathrm{Fe}^{3+}, \mathrm{Cr}^{3+}\right)$, rhodochrosite $\left(\mathrm{MnCO}_{3}\right)$, pyrite $\left(\mathrm{FeS}_{2}\right)$, and sphalerite $(\mathrm{ZnS})$ were also observed as very minor components. Additionally, the XRD patterns of the residue after HF-extraction in the sequential extraction showed that jarosite and galena were also included in a part of the core sediments, though they cannot be detected in the XRD measurements of the original sediment as they are invisible behind strong peaks of $\alpha$-quartz, as below. It is difficult to estimate the vertical distributions of the minor minerals from XRD data, due to very strong peaks assigned to $\alpha$-quartz.

Figure 2 shows an example of changes in XRD patterns by the acid sequential extraction of the sediment between $-100 \mathrm{~cm}$ and $-120 \mathrm{~cm}$. There are clear peaks assigned to $\alpha$-quartz (JCPDS 5-0490), chlorite (JCPDS 16-362) and pyrite (JCPDS 6-0710), and inconspicuous peaks assigned to sericite (JCPDS 2-0056), and rhodochrosite (JCPDS 7-268) in the XRD pattern of the original sample (Fig. 2(a)). The peaks of sphalerite (JCPDS 5-0566) overlap with those of pyrite. After $\mathrm{HCl}$-extraction, the chlorite peaks became weak and the rhodochrosite peaks disappeared while the quartz, sericite, pyrite, and sphalerite peaks were unchanged (Fig. 2(b)). After the HF-extraction, the quartz and sericite peaks disappeared completely while the pyrite and sphalerite peaks were unchanged, and the jarosite $\left(\mathrm{KFe}_{3}\left(\mathrm{SO}_{4}\right)_{2}(\mathrm{OH})_{6}\right.$ : JCPDS 10-443) and galena (PbS: JCPDS 5-0592) peaks became detectable (Fig. 2(c)). After the $\mathrm{HNO}_{3}$-extraction, the core sediments were completely dissolved, and no XRD patterns were obtained for them.

Figure 3 shows the vertical distributions of twelve elements dissolved by the sequential extraction with $\mathrm{HCl}, \mathrm{HF}$, and $\mathrm{HNO}_{3}$. Horizontal axies were converted to the amounts of each element per one gram of the core sediment. The main component is HF-soluble $\mathrm{Si}, 60-80 \%$, which is distributed uniformly (Fig. 3(h)). The HF-soluble Al content was 4-12\% with higher concentrations in the upper zone (Fig. 3(g)). The total dissolved concentration of each element by the sequential extraction was in good agreement with the results of XRF. This supports that the sediment was almost completely decomposed by this extraction method.

Manganese is mainly in $\mathrm{HCl}$-soluble chemical form, and
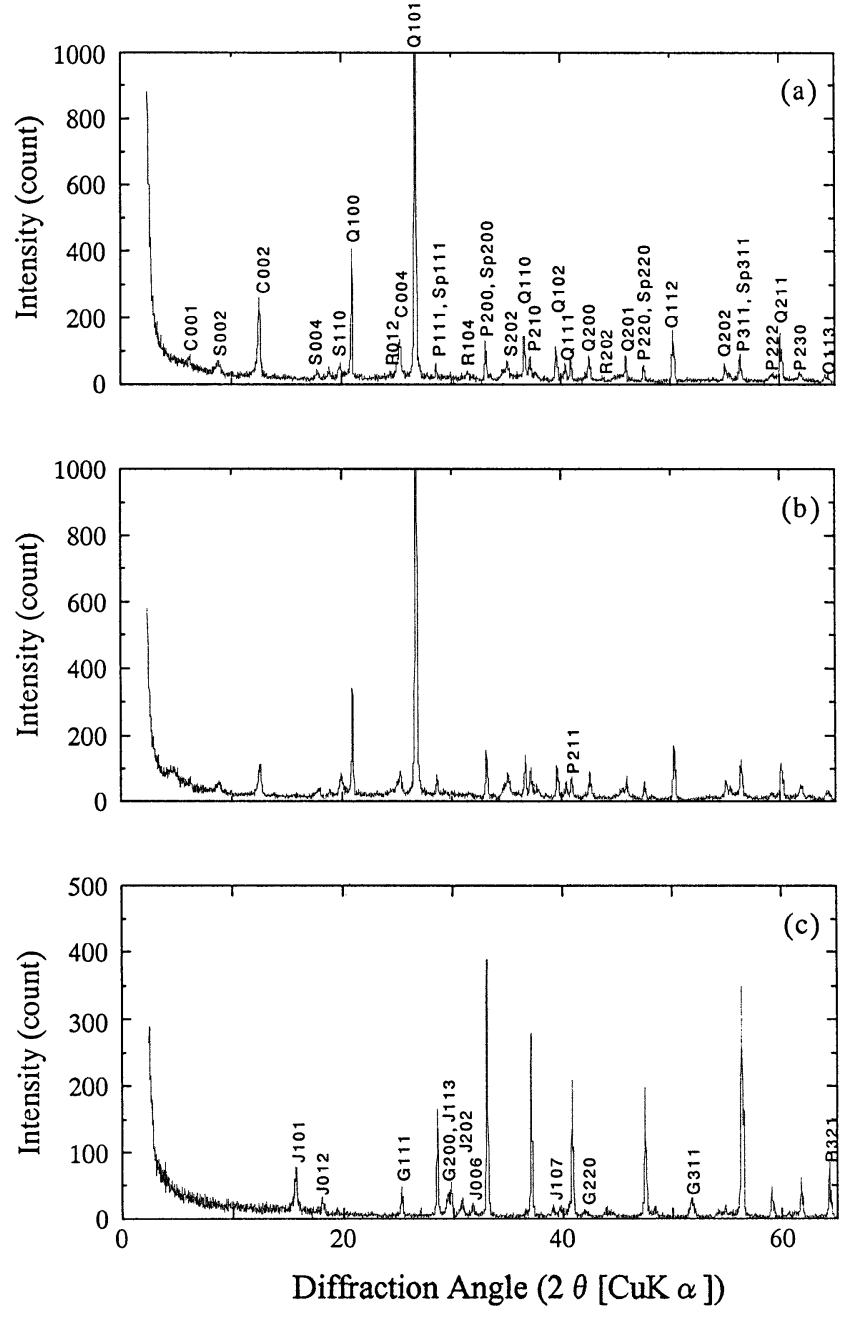

Fig. 2 XRD patterns for the (a) original sediment at $-100 \mathrm{~cm} \sim-120 \mathrm{~cm}$, (b) after $\mathrm{HCl}$-extraction, and (c) after HF-extraction. Q: $\alpha$-quartz (JCPDS 5-0490); C: chlorite (JCPDS 16-362); P: pyrite (JCPDS 6-0710); S: sericite (JCPDS 2-0056); R: rhodochrosite (JCPDS 7-268); Sp: sphalerite (JCPDS 5-0566); J: jarosite (JCPDS 10-443); G: galena (JCPDS 5-0592).

$\mathrm{HF}$ - and $\mathrm{HNO}_{3}$-soluble manganese is minor components (Fig. 3(j)). It is assumed that rhodochrosite is a main source of the high Mn concentrations in mine drainage, and everywhere present below the $-100 \mathrm{~cm}$ zone.

As mentioned above, chlorite was partly dissolved in the $\mathrm{HCl}$-extraction. The distributions of the main components of chlorite, $\mathrm{Fe}, \mathrm{Al}, \mathrm{Si}$ and $\mathrm{Mg}$ are shown in the $\mathrm{HCl}$-extraction of Figs. 3(b), (g), (h), (k)). This emphasizes that the chlorite in the sediments was mainly dissolved by HCl-extraction. As shown in Fig. 2, the chlorite peaks of XRD did not disappear by the $\mathrm{HCl}$-extraction, but disappeared completely after the HF-extraction. Figures 4 and 5 show positive relations for the $\mathrm{Mg}$ and $\mathrm{Fe}$ concentrations versus the $\mathrm{Al}$ concentrations in the HCl-extraction (Figs. 4(b), (c)) and for the Fe concentrations versus the Al concentrations in the HF-extraction (Fig. 5(c)), however, the concentrations of these components were higher in the $\mathrm{HCl}$-extraction than in the HF-extraction. Therefore, it is likely that chlorite was almost all dissolved in the $\mathrm{HCl}$ extraction and that the remainder was completely dissolved in the HF-extraction.

From Figs. 2 and 3(h), it is clear that $\alpha$-quartz was com- 

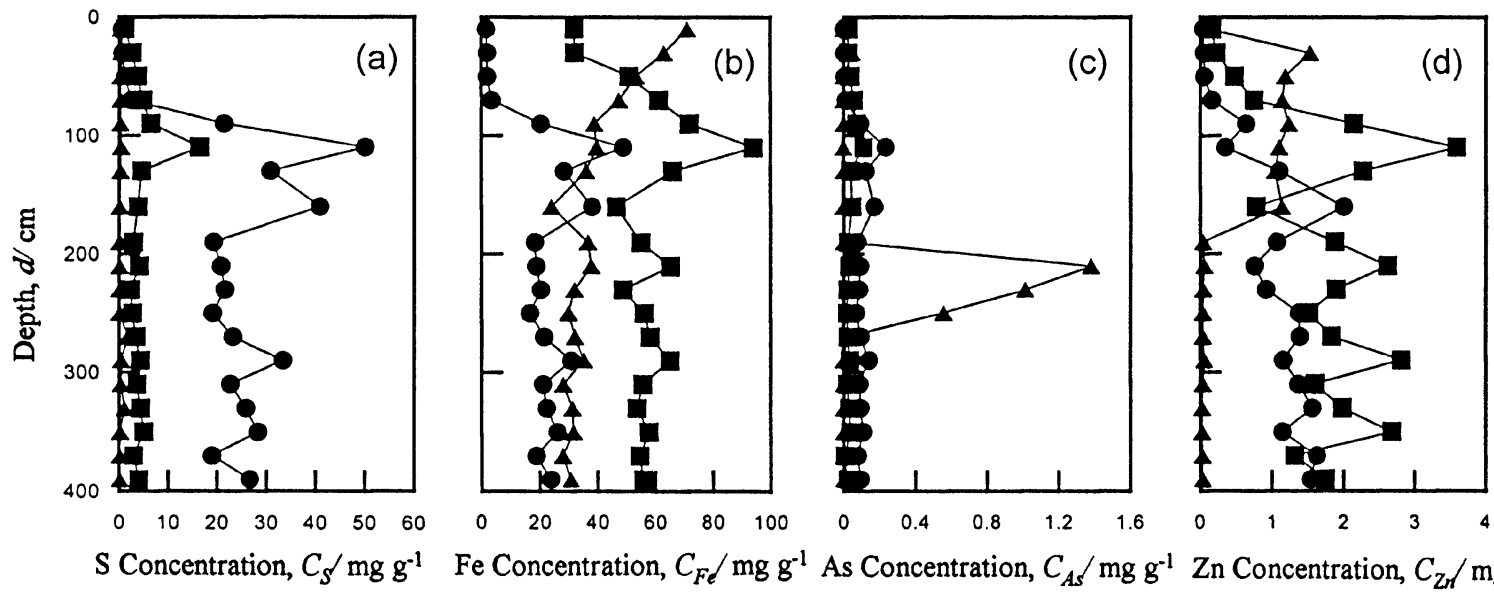

Fe Concentration, $C_{F e} / \mathrm{mg} \mathrm{g}^{-1}$ As Concentration, $C_{A s} / \mathrm{mg} \mathrm{g}^{-1} \mathrm{Zn}$ Concentration, $C_{Z d} / \mathrm{mg} \mathrm{g}^{-1}$
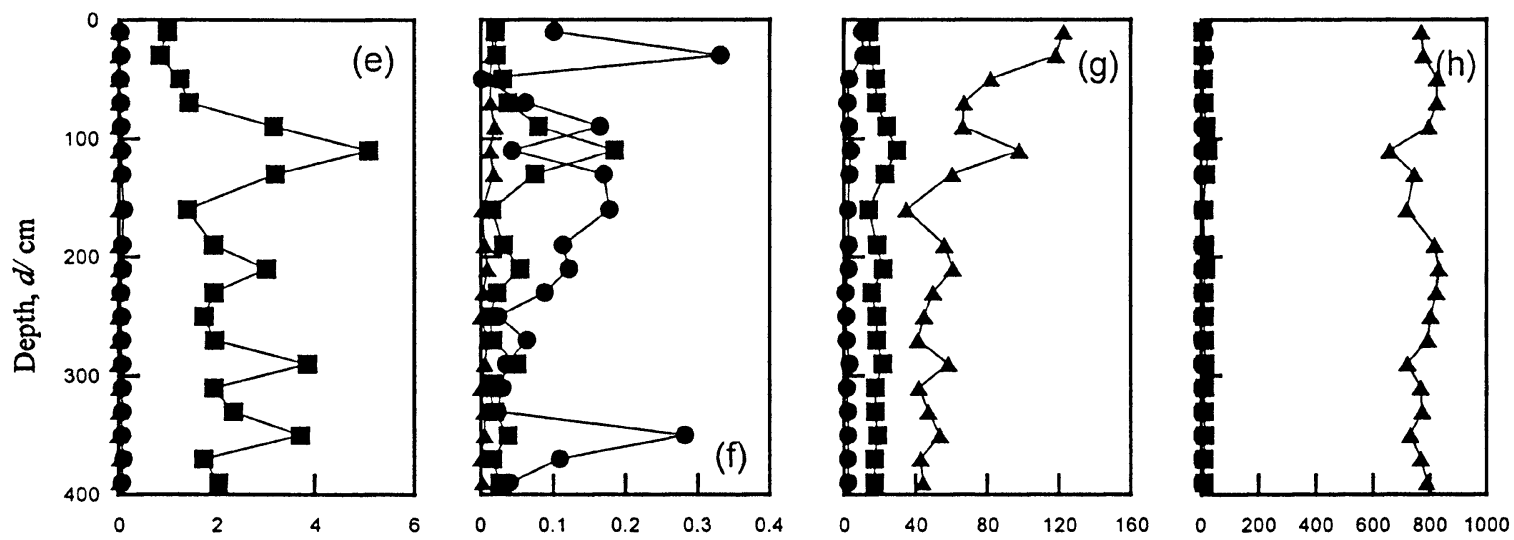

$\mathrm{Pb}$ Concentration, $C_{P b} / \mathrm{mg} \mathrm{g}^{-1}$ Cu Concentration, $C_{C l} / \mathrm{mg} \mathrm{g}^{-1}$ Al Concentration, $C_{A} / \mathrm{mg} \mathrm{g}^{-1} \quad$ Si Concentration, $C_{S l} / \mathrm{mg} \mathrm{g}^{-1}$
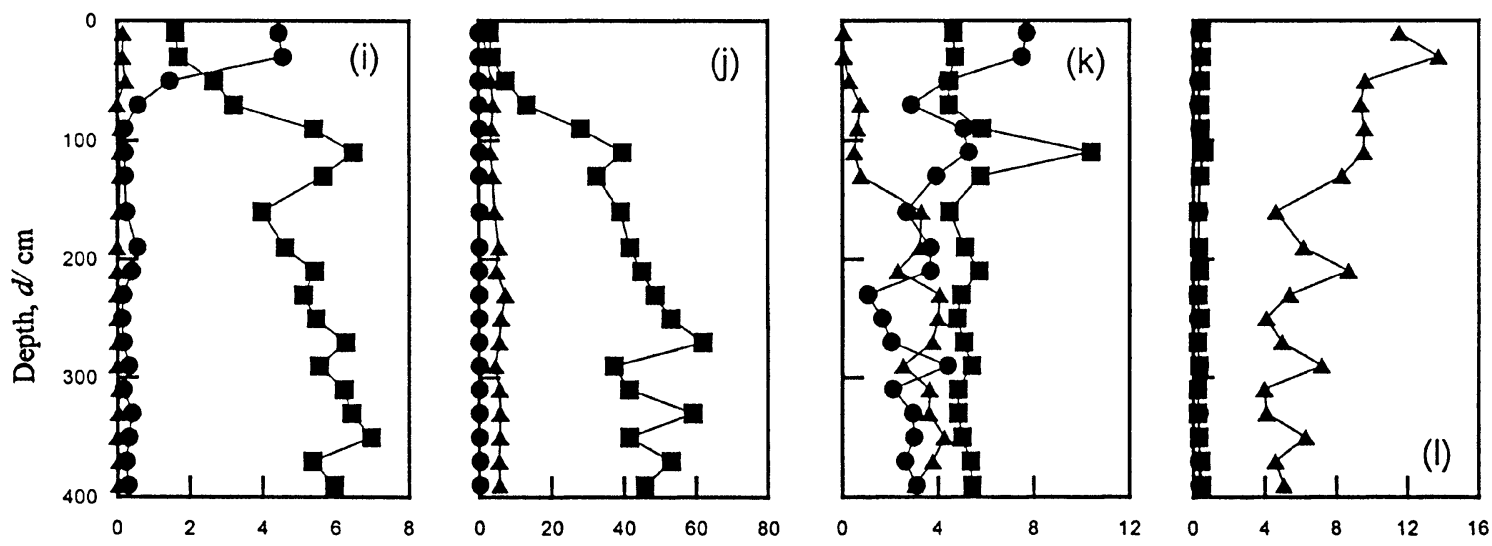

Ca Concentration, $C_{C d} / \mathrm{mg} \mathrm{g}^{-1} \mathrm{Mn}$ Concentration, $C_{M n} / \mathrm{mg} \mathrm{g}^{-1} \mathrm{Mg}$ Concentration, $C_{M g} / \mathrm{mg} \mathrm{g}^{-1} \mathrm{~K}$ Concentration, $C_{K} / \mathrm{mg} \mathrm{g}^{-1}$

Fig. 3 Vertical distribution of (a) S, (b) Fe, (c) As, (d) Zn, (e) Pb, (f) Cu, (g) Al, (h) Si, (i) Ca, (j) Mn, (k) Mg, and (l) K by sequential extraction. Horizontal axis indicates the amount of each element per $1 \mathrm{~g}$ of sediment by $\mathrm{mg} \mathrm{g}^{-1}$. $\mathbf{\square}, \mathrm{HCl} ; \boldsymbol{\Lambda}, \mathrm{HF} ; \boldsymbol{\bullet}, \mathrm{HNO}$.

pletely dissolved in the HF-extraction. As can be seen in Fig. 2, on the other hand, it is not easy to determine the changes in sericite in the sequential extraction from only the XRD patterns, owing to the weak peak intensities. The vertical distributions of the HF-extracted $\mathrm{Al}$ and $\mathrm{K}$ concentrations in Figs. 3(g), (1), have a tendency to increase in upper zone. This indicates that most sericite was dissolved by the HF-extraction, and mainly distributed above $-100 \mathrm{~cm}$. There is a good correlation between the $\mathrm{K}$ and $\mathrm{Al}$ concentrations in the HF-extraction as shown in Fig. 5(a). Clay minerals such as chlorite and sericite were distributed locally in the upper
$-100 \mathrm{~cm}$. In general, clay minerals have agglomerative effects and enhance air and water supply in soil. In the present work, the sediments above $-100 \mathrm{~cm}$ were weakly acidic, oxidative, and low in SRB activity, indicating that the region is aerobic, and easily weathered by the effect of acidic deposits. This would make rhodochrosite easy to dissolve in the upper zone, in good agreement with the above results as shown in Fig. 3(j).

The relationships between the $\mathrm{HNO}_{3}$-extracted heavy metals versus $S$ concentrations are shown in Fig. 6. It can be seen that $\mathrm{Fe}, \mathrm{As}, \mathrm{Zn}, \mathrm{Pb}$ contents have positive relation against $\mathrm{S}$ 

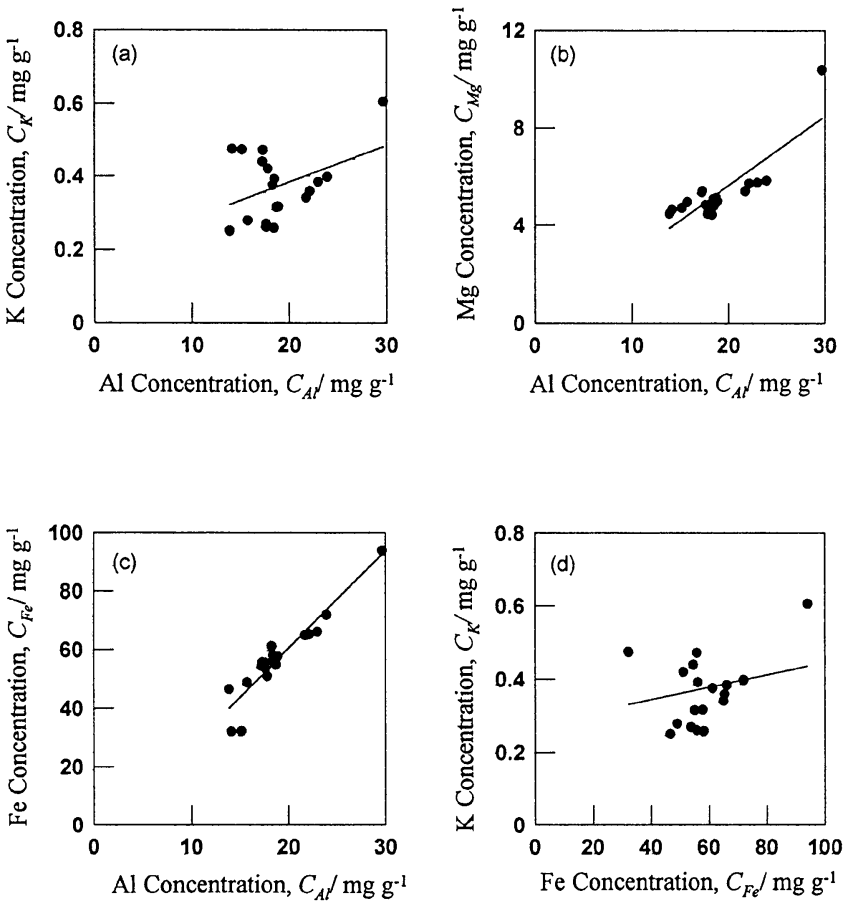

Fig. 4 Interrelationship of (a) $\mathrm{K}$, (b) $\mathrm{Mg}$, and (c) Fe vs. Al concentration, and (d) $\mathrm{K}$ vs. Fe concentration after treatment with $\mathrm{HCl}$ in the sequential extraction of sediments. Straight lines were calculated by the least squares method.
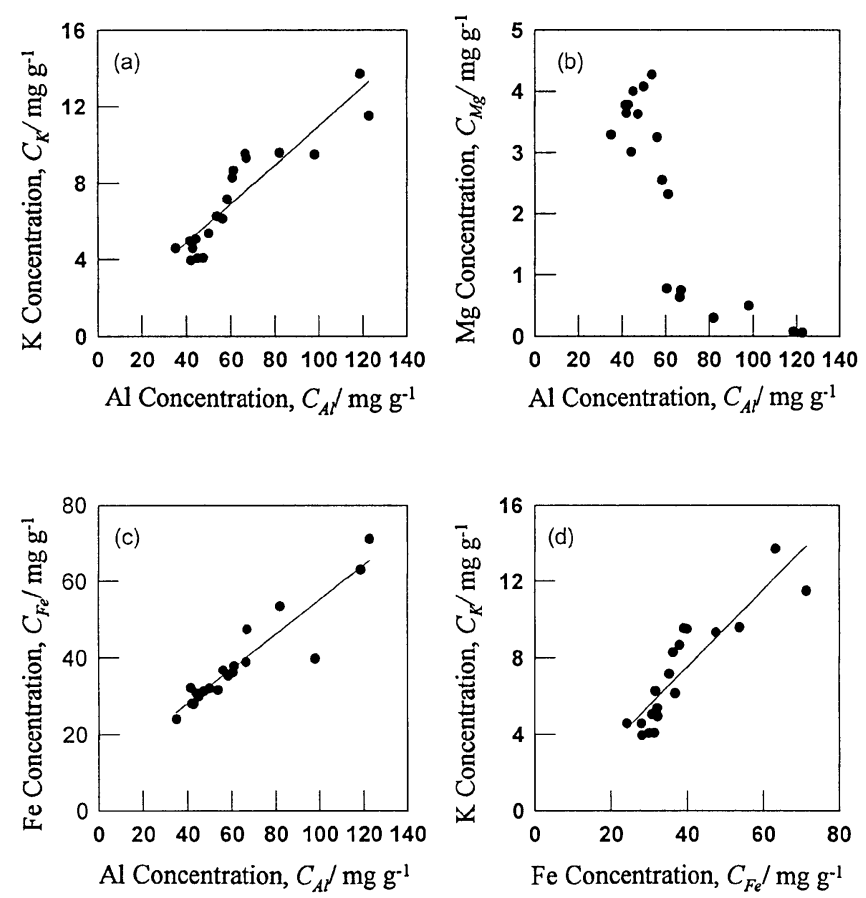

Fig. 5 Interrelationship of (a) $\mathrm{K}$, (b) $\mathrm{Mg}$, and (c) Fe vs. Al concentration, and (d) $\mathrm{K}$ vs. Fe concentration after treatment with $\mathrm{HF}$ in the sequential extraction of sediments. Straight lines were calculated by the least squares method.

content (Figs. 6(a)-(d), though relation of $\mathrm{Cu}$ versus $\mathrm{S}$ was not clear (Fig. 6(e)). Especially from Fig. 6(a), the Fe:S mole ratio is around 1:2 (correlation coefficient 0.9938 ) corresponding to that of pyrite $\left(\mathrm{FeS}_{2}\right)$. This indicates that most sulfides are pyrite which is common at $-100 \mathrm{~cm} \sim-120 \mathrm{~cm}$, the other heavy metals and As are involved in pyrite crystals. It is considered that trace amounts of $\mathrm{As}, \mathrm{Zn}$, and $\mathrm{Pb}$ are involved
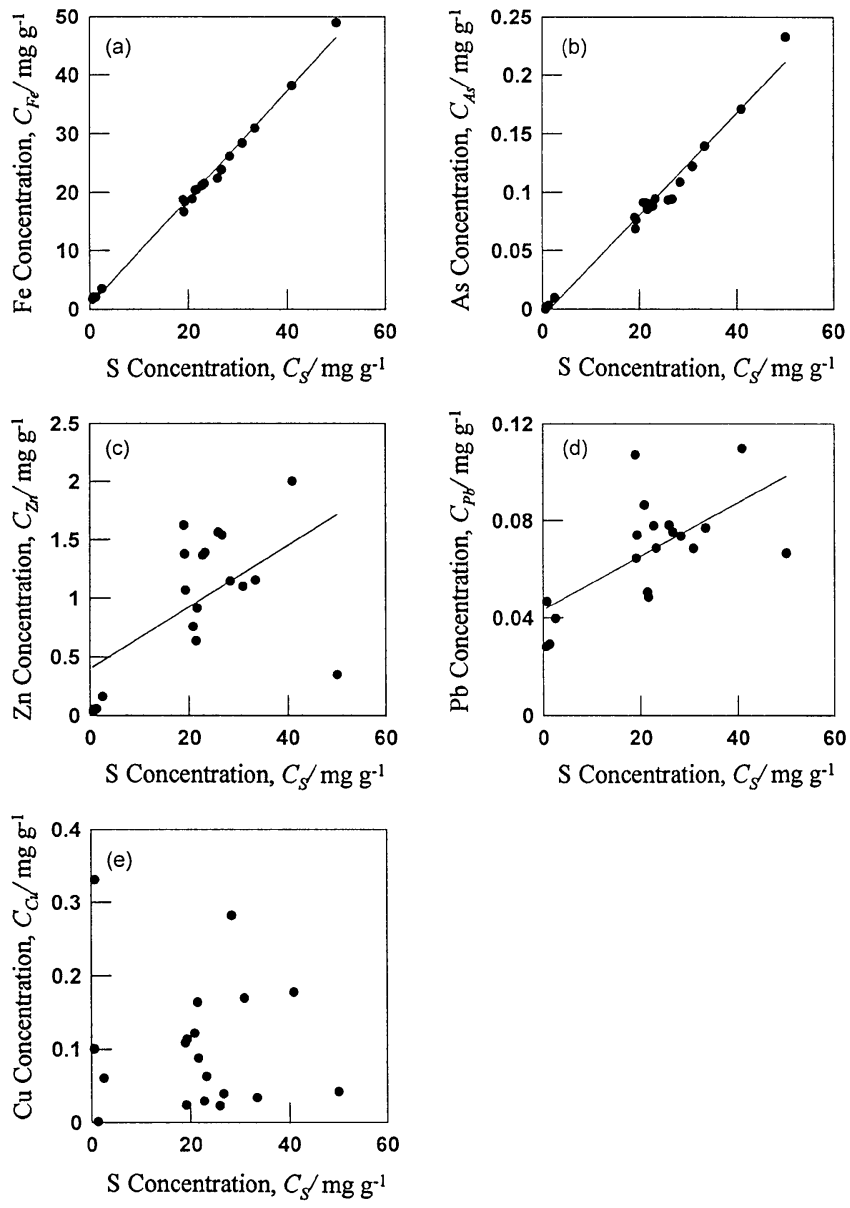

Fig. 6 Interrelationship of (a) Fe, (b) As, (c) $\mathrm{Zn}$, (d) $\mathrm{Pb}$, (e) $\mathrm{Cu}$ vs. S concentration after treatment with $\mathrm{HNO}_{3}$ in the sequential extraction of sediments. Straight lines were calculated by the least squares method.

in sulfides as arsenopyrite, orpiment, sphalerite, and galena.

Jarosite is well known as a secondarily formed mineral formed during $\mathrm{Fe}(\mathrm{II})$ oxidation in strongly acidic environments (e.g. by microbially mediated dissolution of pyrite in mine districts). ${ }^{7}$ A preliminary experiment was carried out: the solubilities of jarosite formed at ambient temperatures $^{9)}$ and synthesized by autoclaving ${ }^{10)}$ were examined. It was found that jarosite formed at ambient temperatures was almost all dissolved by $1 \mathrm{~mol} \mathrm{~L}^{-1} \mathrm{HCl}$-extraction, while jarosite synthesized by autoclaving almost all undissolved by $1 \mathrm{~mol} \mathrm{~L}^{-1} \mathrm{HCl}$-extraction. It was reported that the origin of jarosite as above reflected the peak intensity of IR spectra, that is, the intensity of the covalent bond of crystals. ${ }^{11)}$ It is considered that $\mathrm{HCl}$-insoluble jarosite may be present in the core sample and remain in the final step of the sequential extraction.

To elucidate the minerals that are combined into rhodochrosite, the interrelationships between the $\mathrm{K}, \mathrm{Al}$, and $\mathrm{Si}$ concentrations after the HF-extraction and the Mn concentrations after the $\mathrm{HCl}$-extraction are plotted in Fig. 7. In the HF-extraction, $\mathrm{K}$ is extracted from sericite, $\mathrm{Al}$ from sericite and chlorite, and $\mathrm{Si}$ from sericite, chlorite, and quartz. The interrelations between the $\mathrm{K}$ and $\mathrm{Al}$ concentrations after HF-extraction and the Mn concentrations after $\mathrm{HCl}$-extraction are negative as shown in Figs. 7(a), (b), indicating that neither sericite nor chlorite are associated with 

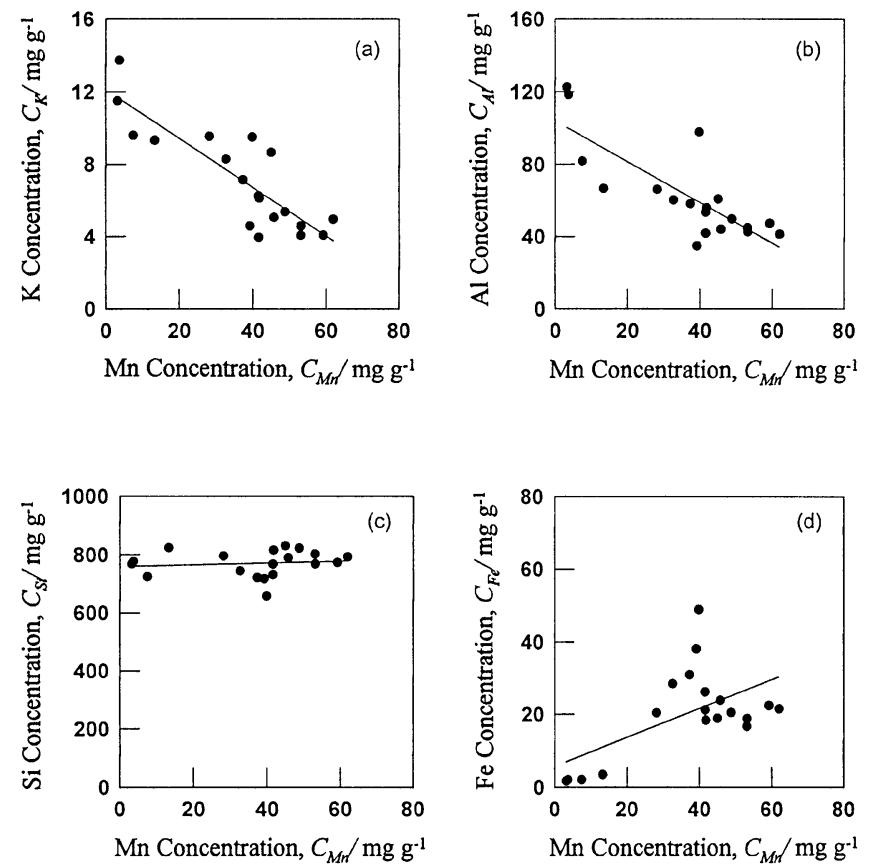

Fig. 7 Interrelationship of (a) K, (b) $\mathrm{Al}$, (c) $\mathrm{Si}$ after HF-extraction, (d) $\mathrm{Fe}$ after $\mathrm{HNO}_{3}$-extraction vs. $\mathrm{Mn}$ after $\mathrm{HCl}$-extraction of sediments. Straight lines were calculated by the least squares method.

rhodochrosite. The distribution of Si concentrations after HFextraction was independent of the Mn concentrations after the $\mathrm{HCl}$-extraction as shown in Fig. 7(c). Quartz is also not associated with rhodochrosite. The interrelation of Fe concentrations after $\mathrm{HNO}_{3}$-extraction and $\mathrm{Mn}$ concentrations after $\mathrm{HCl}$-extraction is positive with relatively large correlation coefficients. This indicates that most of the pyrite is associated with rhodochrosite, though a part of the pyrite grains are independent of rhodochrosite. Dissolution of pyrite promotes the acidification of the district, leading to the decomposition of rhodochrosite. To prevent the dissolution of rhodochrosite, it is important to suppress the weathering of pyrite due to biological and chemical dissolution. Natural organic acids, such as humic substances, are promissing to prevent pyrite from weathering by means of cell inhibition, chelation, reduction and so on. ${ }^{12,13)}$

\section{Conclusions}

The vertical distribution of heavy metals and other elements in sediment core samples in a land fill of abandoned mine tailings were examined. Core samples were analyzed by XRF and XRD, and further examined by sequential ex- traction with $\mathrm{HCl}, \mathrm{HF}$, and $\mathrm{HNO}_{3}$. The conclusions may be summarized as follows:

(1) From the XRD, the core sediment contained $\alpha$-quartz as the main component, and sericite, chlorite, rhodochrosite, pyrite, jarosite, sphalerite, and galena as minor components.

(2) A complete decomposition method for mine tailing sediments at ambient temperatures was established by the advanced sequential extraction.

(3) The acid sequential extraction was useful for the analysis of minerals in mine tailings which is difficult to detect by XRD.

(4) Rhodochrocite and chlorite were dissolved by the $\mathrm{HCl}$-extraction $\alpha$-quartz and sericite by the HF-extraction, and sulfides by the $\mathrm{HNO}_{3}$-extraction.

(5) Rhodochrocite is a main source of the high concentrations of $\mathrm{Mn}$ in mine drainage and was common below the $-100 \mathrm{~cm}$ zone in the mine tailing landfill.

(6) Rhodochrocite was associated with pyrite, but not with sericite and $\alpha$-quartz in the mine tailing landfill. The distribution of most of the heavy metals was related to pyrite.

\section{Acknowledgments}

This work was partly supported by a Grant-in-Aid for Scientific Research (No. 13555275) from the Japan Society for Promotion of Science.

\section{REFERENCES}

1) M. Astrom: Environ. Geol., 36 (1998) 219-226.

2) K. R. Waybrant, D. W. Blowes and C. J. Ptacek: Environ. Sci. Technol., 32 (1998) 1972-1979.

3) D. S. Wray: Environmental Geochemistry and Health-Incoporating Minerals and the Environment, 20 (1998) 29-38.

4) D. Fortin, B. Davis, G. Sotheram and T. J. Beveridge: J. Industrial. Microbiol., 14 (1995) 178-185.

5) D. Fortin and T. J. Beveridge: Geomicrobiol., 14 (1997) 1-12.

6) C. S. Kirby, S. M. Decker and N. K. Macander: Environ. Geol., 37 (1999) 243-254.

7) J. M. Bigham, U. Schwertmann and L. Carlson: Catena [suppl], 21 (1992) 219-232.

8) M. Huerta-Diaz and J. W. Morse: Mar. Chem., 29 (1990) 119-144.

9) K. Sasaki: Can. Mineral., 35 (1997) 999-1008.

10) J. E. Dutrizac and S. Kaiman: Can. Mineral., 14 (1976) 151-158.

11) e.g., K. Sasaki, O. Tanaike, H. Konno: Can. Mineral., 36 (1998) 12251235.

12) K. Sasaki, M. Tsunekawa, S. Tanaka and H. Konno: Colloids and Surfaces A: Physicochemical and Engineering Aspects, 119 (1996) 241253.

13) K. Sasaki, M. Tsunekawa, T. Ohtsuka and H. Konno: Colloids and Surfaces A: Physicochemical and Engineering Aspects, 133 (1998) 269278. 